\title{
Analysis of total metals in waste molding and core sands from ferrous and non-ferrous foundries
}

\author{
Roberto E. Miguel $^{a}$, James A. Ippolito ${ }^{b}$, April B. Leytem $^{b}$, Atilio A. Porta ${ }^{c}$, Roxana B. Banda Noriega ${ }^{a}$, \\ Robert S. Dungan ${ }^{\mathrm{b}, *}$

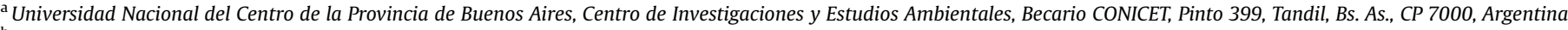 \\ ${ }^{\mathrm{b}}$ USDA-ARS, Northwest Irrigation and Soils Research Laboratory, 3793 North 3600 East, Kimberly, ID 83341, USA \\ ${ }^{\mathrm{c}}$ Universidad Nacional de la Plata, Laboratorio de Ingeniería Sanitaria, 47 and 116, La Plata, CP 1900, Bs. As., Argentina
}

\section{A R T I C L E I N F O}

\section{Article history:}

Received 22 February 2012

Received in revised form

16 May 2012

Accepted 30 May 2012

Available online $\mathrm{xxx}$

\section{Keywords:}

Beneficial use

Binder

Core

Foundry

Metals

Molding sand

\begin{abstract}
A B S T R A C T
Waste molding and core sands from the foundry industry are successfully being used around the world in geotechnical and soil-related applications. Although waste foundry sands (WFSs) are generally not hazardous in nature, relevant data is currently not available in Argentina. This study aimed to quantify metals in waste molding and core sands from foundries using a variety of metal-binder combinations. Metal concentrations in WFSs were compared to those in virgin silica sands (VSSs), surface soils and soil guidance levels. A total analysis for $\mathrm{Ag}, \mathrm{Al}, \mathrm{Ba}, \mathrm{Be}, \mathrm{Cd}, \mathrm{Co}, \mathrm{Cr}, \mathrm{Cu}, \mathrm{Fe}, \mathrm{Mg}, \mathrm{Mn}, \mathrm{Mo}, \mathrm{Ni}, \mathrm{Pb}, \mathrm{Sb}, \mathrm{Te}, \mathrm{Tl}, \mathrm{V}$, and Zn was conducted on 96 WFSs and 14 VSSs collected from 17 small and medium-sized foundries. The majority of WFSs analyzed, regardless of metal cast and binder type, contained metal concentrations similar to those found in VSSs and native soils. In several cases where alkyd urethane binder was used, $\mathrm{Co}$ and $\mathrm{Pb}$ concentrations were elevated in the waste sands. Elevated $\mathrm{Cr}, \mathrm{Mo}, \mathrm{Ni}$, and $\mathrm{Tl}$ concentrations associated with VSSs should not be an issue since these metals are bound within the silica sand matrix. Because of the naturally low metal concentrations found in most WFSs examined in this study, they should not be considered hazardous waste, thus making them available for encapsulated and unencapsulated beneficial use applications.
\end{abstract}

Published by Elsevier Ltd.

\section{Introduction}

Foundries around the world use vast quantities of sand to make metalcasting molds and cores (used to make cavities in molds). The molding sands are created by combining virgin sands with binding agents such as bentonite clay or organic resins. When bentonite clays (e.g. sodium or calcium bentonite) are used as the primary binding agent, the molding sands are then known as green sands. Additional agents are often added to the green sand mixtures such as bituminous coal and cellulosic materials to help produce a reducing atmosphere during casting and prevent casting defects. While green sands are the most commonly used molding system, organic resin binders are almost exclusively used to make molds for non-ferrous castings and cores. Commonly used resins are the phenolic urethane, furan, and Novolac (Dungan and Reeves, 2005), although natural binders such as protein-based (e.g. GMBOND), oils

\footnotetext{
* Corresponding author. Tel.: +1 208423 6553; fax: +1 2084236555 .

E-mail address: robert.dungan@ars.usda.gov (R.S. Dungan).
}

(e.g. flaxseed, soybean), and polysaccharides (e.g. starch) are also available (Carey, 2002; Roa, 2003; Yu et al., 2009).

Once a mold has been produced, molten metal is poured into it, and after cooling the mold is broken apart to retrieve the casting. Depending upon the foundry, the sands can be reclaimed and used to make new molds and cores; however, at some point sand is removed from the system to allow for replacement with new sand. The waste sands are then often disposed of in uncontrolled landfills, sometimes at the foundries, or sent to controlled landfills. Due to high tipping fees, the disposal of sands in controlled landfills is an economic burden to foundries, especially as landfills reach the end of their life expectancy. While there is economic advantage to dispose of waste foundry sands (WFSs) in uncontrolled landfills, this practice could potentially contribute to groundwater pollution (Ham et al., 1987; Riediker et al., 2000; Miguel et al., 2009).

Although disposal regulations for WFSs do vary among countries, the majority of molding sands are not considered to be hazardous in nature (Deng, 2009; Dungan and Dees, 2009; Siddique et al., 2010). As a result, there are efforts underway in countries like Argentina, Brazil, South Africa, and the United States to beneficially use WFSs in geotechnical (e.g. concrete, asphalt, 
road-subbase) and agricultural (e.g. manufactured soils) applications (Lindsay and Logan, 2005; Siddique et al., 2009). Beneficial use of WFSs preserves natural resources by decreasing the demand for virgin materials, conserves energy and reduces greenhouse gas emissions through reduced mining activities, and decreases the economic and environmental burdens of disposal. Despite these potential benefits, many regulators are reluctant to issue beneficial use permits due to limited information about constituent concentrations in WFSs.

Because data are currently limited in Argentina, the purpose of this study was to quantify total metals in waste molding and core sands from foundries using a variety of metal-binder combinations. To bring perspective to the results, the metal concentrations in the WFSs were also compared to concentrations found in virgin silica sands (VSSs) and surface soils and soil guidance levels. A specific focus was placed on examining the metal concentrations in the WFSs as related to the binder type, as some binder components are suspected of causing elevated metals concentrations in the waste sands. The information from this study will be useful to environmental agencies as they develop beneficial use regulations for WFSs.

\section{Materials and methods}

\subsection{Foundry sands}

A total of 110 sand samples were collected from 17 small and medium size iron, steel, aluminum, and bronze foundries located in the province of Buenos Aires, Argentina. Of the total number of samples, 96 were waste molding or core sands originally prepared using either clay or chemical binders (Table 1) and were associated with either iron, steel, aluminum, or bronze castings. For comparative purposes, 14 VSSs were also obtained from the foundries feedstock without further treatment other than drying. From the sand piles, approximately $200 \mathrm{~kg}$ were initially obtained, which was then reduced in size to $0.1 \mathrm{~kg}$ using a quartering method (IRAM, 2003). The samples were then placed into acid-washed 60$\mathrm{mL}$ polypropylene containers and shipped to the USDA-ARS Northwest Irrigation \& Soils Research Laboratory in Kimberly, Idaho, for subsequent analysis.

\subsection{Total metal analyses}

The sands were crushed in a ball mill (Model 2601, Cianflone Scientific Instruments Corp., Pittsburgh, PA, USA) for 2 min to reduce the particle size and promote sample digestion. Then, $0.25 \mathrm{~g}$ of crushed sample was added to Teflon vessels along with $9 \mathrm{~mL}$ of concentrated $\mathrm{HNO}_{3}$ and $3 \mathrm{~mL}$ of concentrated $\mathrm{HCl}$ for microwaveassisted digestion (U.S. EPA, 2007) using a MARS 5 Microwave
Table 2

Summary of the total metal concentrations in the virgin silica and waste foundry sands.

\begin{tabular}{|c|c|c|c|c|c|c|}
\hline \multirow[t]{2}{*}{ Element } & \multirow[t]{2}{*}{ Sand $^{\mathrm{a}}$} & \multicolumn{5}{|c|}{ Concentration $\left(\mathrm{mg} \mathrm{kg}^{-1}\right)^{\mathrm{b}}$} \\
\hline & & Min & Max & Mean & $50 \%$-ile & $95 \%$-ile \\
\hline \multirow[t]{2}{*}{$\mathrm{Ag}$} & $\mathrm{VSS}^{0 / 14}$ & $<0.70$ & - & 0.35 & - & - \\
\hline & WFS $0 / 96$ & $<0.70$ & - & 0.35 & - & - \\
\hline \multirow[t]{2}{*}{$\mathrm{Al}$} & VSS $^{14 / 14}$ & 310 & 807 & 571 & 569 & 802 \\
\hline & $\mathrm{WFS}^{96 / 96}$ & 281 & 15,074 & 1611 & 805 & 6112 \\
\hline \multirow[t]{2}{*}{$\mathrm{Ba}$} & VSS $^{14 / 14}$ & 10.1 & 18.2 & 14.9 & 15.4 & 17.9 \\
\hline & WFS $^{96 / 96}$ & 7.14 & 115 & 17.6 & 13.8 & 40.2 \\
\hline \multirow[t]{2}{*}{$\mathrm{Be}$} & $\mathrm{VSS}^{2 / 14}$ & $<0.07$ & 0.20 & 0.05 & 0.04 & 0.16 \\
\hline & $\mathrm{WFS}^{5 / 96}$ & $<0.07$ & 0.64 & 0.05 & 0.04 & 0.08 \\
\hline \multirow[t]{2}{*}{$\mathrm{Cd}$} & $\mathrm{VSS}^{5 / 14}$ & $<0.20$ & 0.30 & 0.16 & 0.10 & 0.29 \\
\hline & $\mathrm{WFS}^{40 / 96}$ & $<0.20$ & 0.97 & 0.22 & 0.10 & 0.55 \\
\hline \multirow[t]{2}{*}{ Co } & VSS $^{13 / 14}$ & $<0.70$ & 2.02 & 1.20 & 1.13 & 1.91 \\
\hline & $\mathrm{WFS}^{92 / 96}$ & $<0.70$ & 77.1 & 6.69 & 1.78 & 27.7 \\
\hline \multirow[t]{2}{*}{$\mathrm{Cr}$} & $\mathrm{VSS}^{14 / 14}$ & 605 & 873 & 666 & 641 & 781 \\
\hline & WFS $^{96 / 96}$ & 297 & 931 & 613 & 600 & 818 \\
\hline \multirow[t]{2}{*}{$\mathrm{Cu}$} & VSS $^{14 / 14}$ & 2.03 & 8.61 & 6.06 & 6.27 & 8.03 \\
\hline & $\mathrm{WFS}^{94 / 96}$ & $<0.5$ & 303 & 13.9 & 5.62 & 37.7 \\
\hline \multirow[t]{2}{*}{$\mathrm{Fe}$} & VSS $^{14 / 14}$ & 5058 & 6940 & 5881 & 5922 & 6628 \\
\hline & WFS $^{96 / 96}$ & 4769 & 18,217 & 8038 & 6984 & 15,636 \\
\hline \multirow[t]{2}{*}{$\mathrm{Mg}$} & $\mathrm{VSS}^{0 / 14}$ & $<0.20$ & - & 0.10 & - & - \\
\hline & $\mathrm{WFS}^{31 / 96}$ & $<0.20$ & 4002 & 190 & 0.10 & 1207 \\
\hline \multirow[t]{2}{*}{ Mn } & VSS $^{14 / 14}$ & 38.6 & 67.3 & 51.7 & 50.8 & 61.4 \\
\hline & WFS $^{96 / 96}$ & 34.2 & 202 & 68.7 & 60.2 & 131 \\
\hline \multirow[t]{2}{*}{ Mo } & $\mathrm{VSS}^{14 / 14}$ & 5.57 & 13.2 & 9.15 & 8.75 & 13.1 \\
\hline & WFS $^{96 / 96}$ & 0.99 & 20.8 & 8.49 & 8.04 & 13.4 \\
\hline \multirow[t]{2}{*}{$\mathrm{Ni}$} & $\mathrm{VSS}^{14 / 14}$ & 133 & 197 & 147 & 143 & 181 \\
\hline & $\mathrm{WFS}^{96 / 96}$ & 40.8 & 260 & 137 & 138 & 175 \\
\hline \multirow[t]{2}{*}{$\mathrm{Pb}$} & $\mathrm{VSS}^{0 / 14}$ & $<4.20$ & - & 2.10 & - & - \\
\hline & $\mathrm{WFS}^{46 / 96}$ & $<4.20$ & 647 & 51.4 & 2.10 & 265 \\
\hline \multirow[t]{2}{*}{$\mathrm{Sb}$} & $\mathrm{VSS}^{7 / 14}$ & $<3.20$ & 4.23 & 2.64 & 2.48 & 4.23 \\
\hline & WFS $^{45 / 96}$ & $<3.20$ & 4.39 & 2.64 & 1.60 & 4.22 \\
\hline \multirow[t]{2}{*}{$\mathrm{Te}$} & $\mathrm{VSS}^{0 / 14}$ & $<4.00$ & - & 2.00 & - & - \\
\hline & WFS $^{0 / 96}$ & $<4.00$ & - & 2.00 & - & - \\
\hline \multirow[t]{2}{*}{$\mathrm{Tl}$} & $\mathrm{VSS}^{0 / 14}$ & $<12.0$ & - & 6.00 & - & - \\
\hline & $\mathrm{WFS}^{0 / 96}$ & $<12.0$ & - & 6.00 & - & - \\
\hline \multirow[t]{2}{*}{ V } & VSS $^{14 / 14}$ & 4.06 & 7.32 & 5.87 & 5.87 & 7.16 \\
\hline & WFS $^{96 / 96}$ & 3.49 & 25.7 & 7.89 & 6.63 & 16.5 \\
\hline \multirow[t]{2}{*}{$\mathrm{Zn}$} & $\mathrm{VSS}^{14 / 14}$ & 8.62 & 17.4 & 10.5 & 9.82 & 15.3 \\
\hline & $\mathrm{WFS}^{96 / 96}$ & 6.06 & 171 & 21.2 & 13.1 & 57.9 \\
\hline
\end{tabular}

a VSS, virgin silica sand; WFS, waste foundry sand; the numbers following the abbreviations represent the number of detects above the MDL

$\mathrm{b}$ Calculations based on setting sample concentrations $<\mathrm{MDL}$ at one half that value.

Accelerated Reaction System (CEM Corp., Matthews, NC, USA). After digestion, the samples were brought to $25 \mathrm{~mL}$ in volumetric flasks with deionized water and then filtered using $0.45 \mu \mathrm{m}$ polypropylene syringe filters. The filtrate was stored in $15 \mathrm{~mL}$ polypropylene tubes (Corning, Lowell, MA, USA) at $4{ }^{\circ} \mathrm{C}$ until analyzed by inductively coupled plasma-optical emission spectroscopy for

Table 1

Binder systems associated with the waste foundry sands analyzed in this study. ${ }^{\mathrm{a}}$

\begin{tabular}{|c|c|c|c|c|}
\hline Binder system & Binder components & Sand (\%) & Binder (\%) & No. of samples \\
\hline Alkyd Urethane & $\begin{array}{l}\text { Linseed oil based alkyd urethane. Some proprietary binder components contain } \mathrm{Pb} \text { and } \mathrm{Co} \\
\text { octanoates to enhance the curing velocity }\end{array}$ & $98-99.2$ & $0.8-2$ & 28 \\
\hline Phenolic & $\begin{array}{l}\text { Phenolic containing resins included resole and furan. Resoles are prepared by a reaction of } \\
\text { excess formaldehyde with phenol and the addition of a base catalyst. Furan is a furfuryl alcohol } \\
\text { based resin made with an acid catalyst and either phenol-formaldehyde and other chemical } \\
\text { additives depending upon the formula }\end{array}$ & $98.5-98.8$ & $1.2-1.5$ & $23^{\mathrm{b}}$ \\
\hline Shell & $\begin{array}{l}\text { Phenol-formaldehyde based resin consisting of Novolac oligomers that cross-polymerize when } \\
\text { heated in the presence of hexamethylenetetramine }\end{array}$ & $97-98$ & $2-3$ & 17 \\
\hline Green Sand & $\begin{array}{l}\text { A mixture of sodium and/or calcium bentonite is used as the binder, but additional additives } \\
\text { include bituminous coal, cellulose, and water }\end{array}$ & $85-90$ & $10-15$ & 14 \\
\hline Natural Binders & Aqueous emulsion with a mixture of soybean oil, polysaccharides, reducing sugars, and water & 97 & 3 & 9 \\
\hline Unknown & Miscellaneous comingled waste sands & - & - & 5 \\
\hline
\end{tabular}

a 72 iron, 9 steel, 12 aluminum, and 3 bronze samples were collected.

b Only 2 of 23 sands were furan based. 
the following metals: $\mathrm{Ag}, \mathrm{Al}, \mathrm{Ba}, \mathrm{Be}, \mathrm{Cd}, \mathrm{Co}, \mathrm{Cr}, \mathrm{Cu}, \mathrm{Fe}, \mathrm{Mg}, \mathrm{Mn}, \mathrm{Mo}$, $\mathrm{Ni}, \mathrm{Pb}, \mathrm{Sb}, \mathrm{Te}, \mathrm{Tl}, \mathrm{V}$, and $\mathrm{Zn}$. Quality control operations included the digestion and analysis of blanks and standard reference material 2709 (San Joaquin Soil, National Institute of Standards and Technology, Gaithersburg, MD, USA).

\section{Results and discussion}

In this study, waste sands from ferrous and non-ferrous foundries were analyzed for total metal concentrations to assess their potential for beneficial use. Most of the samples were obtained from foundries that utilized either alkyd urethane (AU), phenol-formaldehyde, or bentonite based binder systems. A complete description of the binding agents associated with the WFSs is listed in Table 1. During the casting process any added organic additives and resins undergo thermal decomposition to produce a number of volatile and non-volatile organic compounds (Dungan and Reeves, 2005, 2007a). However, under most circumstances not all of the resin will undergo thermal decomposition; thus, any original components of the resins will be retained by the

Table 3

Breakdown of the total metal concentrations in the waste foundry sands by binder type used.

\begin{tabular}{|c|c|c|c|c|c|c|c|c|c|c|c|}
\hline \multirow[t]{2}{*}{ Element } & \multirow[t]{2}{*}{ Sand $^{\mathrm{a}}$} & \multicolumn{4}{|c|}{ Concentration $\left(\mathrm{mg} \mathrm{kg}^{-1}\right)^{\mathrm{b}}$} & \multirow[t]{2}{*}{ Element } & \multirow[t]{2}{*}{ Sand } & \multicolumn{4}{|c|}{ Concentration $\left(\mathrm{mg} \mathrm{kg}^{-1}\right)$} \\
\hline & & Min & Max & Mean & $50 \%$-ile & & & Min & Max & Mean & $50 \%$-ile \\
\hline \multirow[t]{7}{*}{$\mathrm{Al}$} & $\mathrm{VSS}^{14 / 14}$ & 310 & 807 & 572 & 569 & \multirow[t]{7}{*}{$\mathrm{Mg}$} & $\mathrm{VSS}^{0 / 14}$ & $<0.20$ & - & 0.10 & - \\
\hline & $\mathrm{AU}^{28 / 28}$ & 286 & 2973 & 863 & 721 & & $\mathrm{AU}^{7 / 28}$ & $<0.20$ & 381 & 37.2 & 0.10 \\
\hline & $\mathrm{PHL}^{23 / 23}$ & 281 & 1823 & 622 & 554 & & $\mathrm{PHL}^{1 / 23}$ & $<0.20$ & 29.1 & 1.36 & 0.10 \\
\hline & $\mathrm{SHL}^{17 / 17}$ & 542 & 1870 & 1043 & 1014 & & $\mathrm{SHL}^{5 / 17}$ & $<0.20$ & 176 & 31.9 & 0.10 \\
\hline & $\mathrm{GS}^{14 / 14}$ & 864 & 15,074 & 5898 & 5840 & & $\mathrm{GS}^{13 / 14}$ & $<0.20$ & 4002 & 1131 & 1065 \\
\hline & $\mathrm{NAT}^{9 / 9}$ & 329 & 1689 & 871 & 898 & & $\mathrm{NAT}^{4 / 9}$ & $<0.20$ & 213 & 47.4 & 0.10 \\
\hline & $\mathrm{UKN}^{5 / 5}$ & 331 & 3270 & 1625 & 1267 & & $\mathrm{UNK}^{1 / 5}$ & $<0.20$ & 383 & 76.7 & 0.10 \\
\hline \multirow[t]{7}{*}{$\mathrm{Ba}$} & $\mathrm{VSS}^{14 / 14}$ & 10.1 & 18.2 & 14.9 & 15.4 & \multirow[t]{7}{*}{ Mn } & $\mathrm{VSS}^{14 / 14}$ & 38.6 & 67.3 & 51.7 & 50.8 \\
\hline & $\mathrm{AU}^{28 / 28}$ & 7.14 & 23.8 & 13.9 & 14.2 & & $\mathrm{AU}^{28 / 28}$ & 34.2 & 99.4 & 57.0 & 55.9 \\
\hline & $\mathrm{PHL}^{23 / 23}$ & 9.86 & 25.5 & 13.2 & 11.7 & & $\mathrm{PHL}^{23 / 23}$ & 41.8 & 110 & 62.5 & 54.1 \\
\hline & $\mathrm{SHL}^{17 / 17}$ & 8.47 & 23.6 & 13.4 & 13.1 & & $\mathrm{SHL}^{17 / 17}$ & 43.3 & 105 & 64.5 & 59.9 \\
\hline & $\mathrm{GS}^{14 / 14}$ & 9.89 & 115 & 39.3 & 33.8 & & $\mathrm{GS}^{14 / 14}$ & 43.3 & 162 & 105 & 113 \\
\hline & $\mathrm{NAT}^{9 / 9}$ & 9.09 & 17.5 & 13.5 & 12.6 & & $\mathrm{NAT}^{9 / 9}$ & 45.3 & 66.3 & 55.0 & 53.6 \\
\hline & $\mathrm{UNK}^{5 / 5}$ & 11.7 & 30.7 & 18.1 & 17.1 & & $\mathrm{UNK}^{5 / 5}$ & 49.5 & 202 & 99.4 & 71.3 \\
\hline \multirow[t]{7}{*}{ Be } & $\mathrm{VSS}^{2 / 14}$ & $<0.07$ & 0.20 & 0.05 & 0.04 & \multirow[t]{7}{*}{ Mo } & VSS $^{14 / 14}$ & 5.57 & 13.2 & 9.15 & 8.75 \\
\hline & $\mathrm{AU}^{0 / 28}$ & $<0.07$ & - & 0.04 & - & & $\mathrm{AU}^{28 / 28}$ & 2.47 & 13.3 & 8.05 & 8.17 \\
\hline & $\mathrm{PHL}^{5 / 23}$ & $<0.07$ & 0.64 & 0.11 & 0.04 & & $\mathrm{PHL}^{23 / 23}$ & 3.37 & 14.6 & 8.81 & 9.58 \\
\hline & $\mathrm{SHL}^{0 / 17}$ & $<0.07$ & - & 0.04 & - & & $\mathrm{SHL}^{17 / 17}$ & 4.56 & 20.8 & 10.2 & 8.99 \\
\hline & $\mathrm{GS}^{0 / 14}$ & $<0.07$ & - & 0.04 & - & & $\mathrm{GS}^{14 / 14}$ & 0.99 & 10.9 & 6.48 & 6.88 \\
\hline & $\mathrm{NAT}^{0 / 9}$ & $<0.07$ & - & 0.04 & - & & $\mathrm{NAT}^{9 / 9}$ & 5.61 & 12.1 & 8.50 & 8.07 \\
\hline & $\mathrm{UNK}^{0 / 5}$ & $<0.07$ & - & 0.04 & - & & $\mathrm{UNK}^{5 / 5}$ & 6.51 & 16.1 & 9.18 & 7.44 \\
\hline \multirow[t]{7}{*}{ Cd } & $\mathrm{VSS}^{5 / 14}$ & $<0.20$ & 0.30 & 0.16 & 0.10 & \multirow[t]{7}{*}{$\mathrm{Ni}$} & $\mathrm{VSS}^{14 / 14}$ & 133 & 197 & 146 & 143 \\
\hline & $\mathrm{AU}^{5 / 28}$ & $<0.20$ & 0.45 & 0.13 & 0.10 & & $\mathrm{AU}^{28 / 28}$ & 98.4 & 177 & 137 & 135 \\
\hline & $\mathrm{PHL}^{9 / 23}$ & $<0.20$ & 0.35 & 0.18 & 0.10 & & $\mathrm{PHL}^{23 / 23}$ & 121 & 257 & 152 & 146 \\
\hline & $\mathrm{SHL}^{11 / 17}$ & $<0.20$ & 0.60 & 0.31 & 0.26 & & $\mathrm{SHL}^{17 / 17}$ & 104 & 177 & 139 & 141 \\
\hline & $G S^{10 / 14}$ & $<0.20$ & 0.97 & 0.43 & 0.49 & & $\mathrm{GS}^{14 / 14}$ & 40.8 & 147 & 105 & 105 \\
\hline & $\mathrm{NAT}^{1 / 9}$ & $<0.20$ & 0.27 & 0.12 & 0.10 & & $\mathrm{NAT}^{9 / 9}$ & 105 & 177 & 144 & 148 \\
\hline & $\mathrm{UNK}^{4 / 5}$ & $<0.20$ & 0.41 & 0.27 & 0.28 & & $\mathrm{UNK}^{5 / 5}$ & 90.4 & 164 & 134 & 138 \\
\hline Co & $\mathrm{VSS}^{13 / 14}$ & $<0.70$ & 2.02 & 1.20 & 1.13 & $\mathrm{~Pb}$ & $\mathrm{VSS}^{0 / 14}$ & $<4.20$ & - & 2.10 & 2.10 \\
\hline & $\mathrm{AU}^{28 / 28}$ & 3.03 & 77.1 & 19.0 & 8.41 & & $\mathrm{AU}^{28 / 28}$ & 35.6 & 647 & 163 & 66.1 \\
\hline & $\mathrm{PHL}^{22 / 23}$ & $<0.70$ & 2.64 & 1.26 & 1.24 & & $\mathrm{PHL}^{0 / 23}$ & $<4.20$ & - & 2.10 & - \\
\hline & $\mathrm{SHL}^{15 / 17}$ & $<0.70$ & 2.08 & 1.31 & 1.43 & & $\mathrm{SHL}^{1 / 17}$ & $<4.20$ & 7.22 & 2.40 & 2.10 \\
\hline & $\mathrm{GS}^{13 / 14}$ & $<0.70$ & 3.90 & 2.23 & 1.97 & & $\mathrm{GS}^{10 / 14}$ & $<4.20$ & 30.5 & 8.54 & 6.01 \\
\hline & $\mathrm{NAT}^{9 / 9}$ & 0.81 & 3.60 & 1.96 & 1.73 & & $\mathrm{NAT}^{6 / 9}$ & $<4.20$ & 40.7 & 11.8 & 11.9 \\
\hline & $\mathrm{UNK}^{5 / 5}$ & 0.77 & 5.22 & 1.88 & 1.13 & & $\mathrm{UNK}^{1 / 5}$ & $<4.20$ & 48.1 & 11.3 & 2.10 \\
\hline $\mathrm{Cr}$ & VSS $^{14 / 14}$ & 605 & 873 & 666 & 641 & $\mathrm{Sb}$ & $\mathrm{VSS}^{7 / 14}$ & $<3.20$ & 4.23 & 2.64 & 2.48 \\
\hline & $\mathrm{AU}^{28 / 28}$ & 480 & 931 & 630 & 609 & & $\mathrm{AU}^{8 / 28}$ & $<3.20$ & 4.10 & 2.19 & 1.60 \\
\hline & $\mathrm{PHL}^{23 / 23}$ & 511 & 817 & 638 & 641 & & $\mathrm{PHL}^{14 / 23}$ & $<3.20$ & 4.39 & 3.05 & 3.67 \\
\hline & $\mathrm{SHL}^{17 / 17}$ & 468 & 851 & 640 & 657 & & $\mathrm{SHL}^{6 / 17}$ & $<3.20$ & 4.16 & 2.41 & 1.60 \\
\hline & $\mathrm{GS}^{14 / 14}$ & 297 & 695 & 505 & 515 & & $\mathrm{GS}^{8 / 14}$ & $<3.20$ & 4.26 & 2.92 & 3.50 \\
\hline & $\mathrm{NAT}^{9 / 9}$ & 408 & 775 & 648 & 676 & & $\mathrm{NAT}^{6 / 9}$ & $<3.20$ & 4.32 & 3.12 & 3.64 \\
\hline & $\mathrm{UNK}^{5 / 5}$ & 423 & 664 & 543 & 553 & & $\mathrm{UNK}^{3 / 5}$ & $<3.20$ & 4.02 & 2.51 & 1.60 \\
\hline $\mathrm{Cu}$ & $\mathrm{VSS}^{14 / 14}$ & 2.03 & 8.61 & 6.06 & 6.27 & V & $\mathrm{VSS}^{14 / 14}$ & 4.06 & 7.32 & 5.87 & 5.87 \\
\hline & $\mathrm{AU}^{26 / 28}$ & $<0.50$ & 303 & 21.5 & 5.78 & & $\mathrm{AU}^{28 / 28}$ & 4.11 & 12.1 & 6.43 & 5.58 \\
\hline & $\mathrm{PHL}^{22 / 23}$ & $<0.50$ & 12.5 & 5.01 & 4.78 & & $\mathrm{PHL}^{23 / 23}$ & 3.49 & 11.9 & 5.94 & 5.64 \\
\hline & $\mathrm{SHL}^{17 / 17}$ & 3.22 & 43.7 & 8.75 & 5.35 & & $\mathrm{SHL}^{17 / 17}$ & 5.89 & 11.2 & 8.17 & 8.23 \\
\hline & $\mathrm{GS}^{14 / 14}$ & 4.70 & 45.9 & 18.5 & 13.2 & & $\mathrm{GS}^{14 / 14}$ & 4.89 & 25.7 & 14.7 & 15.3 \\
\hline & $\mathrm{NAT}^{9 / 9}$ & 3.16 & 28.7 & 11.4 & 6.00 & & $\mathrm{NAT}^{9 / 9}$ & 4.72 & 8.80 & 6.29 & 5.52 \\
\hline & $\mathrm{UNK}^{5 / 5}$ & 1.52 & 62.0 & 21.5 & 18.6 & & $\mathrm{UNK}^{5 / 5}$ & 4.43 & 15.7 & 7.81 & 6.04 \\
\hline $\mathrm{Fe}$ & VSS $^{14 / 14}$ & 5058 & 6940 & 5881 & 5922 & $\mathrm{Zn}$ & $\mathrm{VSS}^{14 / 14}$ & 8.62 & 17.4 & 10.5 & 9.82 \\
\hline & $\mathrm{AU}^{28 / 28}$ & 4769 & 9416 & 6606 & 6331 & & $\mathrm{AU}^{28 / 28}$ & 6.06 & 171 & 21.3 & 12.2 \\
\hline & $\mathrm{PHL}^{23 / 23}$ & 5371 & 11,262 & 7252 & 6617 & & $\mathrm{PHL}^{23 / 23}$ & 6.40 & 81.9 & 17.6 & 12.5 \\
\hline & $\mathrm{SHL}^{17 / 17}$ & 5707 & 17,075 & 8089 & 7259 & & $\mathrm{SHL}^{17 / 17}$ & 8.11 & 27.8 & 13.6 & 12.2 \\
\hline & $\mathrm{GS}^{14 / 14}$ & 5970 & 18,217 & 12,482 & 13,628 & & $\mathrm{GS}^{14 / 14}$ & 11.1 & 58.4 & 36.5 & 35.5 \\
\hline & $\mathrm{NAT}^{9 / 9}$ & 5744 & 7582 & 6795 & 6878 & & $\mathrm{NAT}^{9 / 9}$ & 8.39 & 30.6 & 14.4 & 11.9 \\
\hline & $\mathrm{UNK}^{5 / 5}$ & 5609 & 12,592 & 9288 & 9419 & & $\mathrm{UNK}^{5 / 5}$ & 8.85 & 84.8 & 32.2 & 21.9 \\
\hline
\end{tabular}

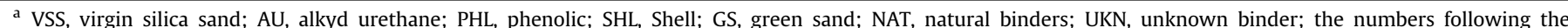
abbreviations represent the number of detects above the MDL.

b Calculations based on setting sample concentrations $<$ MDL at one half that value. 
sands (Dungan and Reeves, 2007b). While most resin components are organic in nature, some phenolic resins are manufactured using divalent metal salts (e.g. based on $\mathrm{Cd}, \mathrm{Co}, \mathrm{Cu}, \mathrm{Mg}, \mathrm{Ni}, \mathrm{Pb}$, and $\mathrm{Zn}$ ) to increase ortho orientation (Gardziella et al., 1999). Unfortunately, the presence of heavy metals in the resins can potentially lead to elevated concentrations within the WFSs (Miguel et al., 2011).

The total metal concentrations in the VSSs and WFSs are presented in Table 2 . In the WFSs, 16 of 19 metals ( $\mathrm{Al}, \mathrm{Ba}, \mathrm{Be}, \mathrm{Cd}, \mathrm{Co}, \mathrm{Cr}$, $\mathrm{Cu}, \mathrm{Fe}, \mathrm{Mg}, \mathrm{Mn}, \mathrm{Mo}, \mathrm{Ni}, \mathrm{Pb}, \mathrm{Sb}, \mathrm{V}$, and $\mathrm{Zn}$ ) were detected in at least one sample above the method detection limit (MDL). All WFS samples (and VSSs) though were found to contain $\mathrm{Ag}$, Te, and $\mathrm{Tl}$ below the MDLs of $<0.70,<4.0$, and $<12.0 \mathrm{mg} \mathrm{kg}^{-1}$, respectively. In general, the mean metal concentrations in the WFSs were greater than or equivalent to those found in the VSSs. This result demonstrates that metals are being added to the sands when the resin binders are used to make the molds and cores and/or during the casting process. The largest difference in mean metal concentrations between the WFSs and VSSs was noted for $\mathrm{Al}$ and Fe, which can be attributed to the fact that waste sands were obtained from foundries that cast these metals. The respective mean $\mathrm{Al}$ and $\mathrm{Fe}$ concentrations in the VSSs were 571 and $5881 \mathrm{mg} \mathrm{kg}^{-1}$, while in the WFSs they were 1611 and $8038 \mathrm{mg} \mathrm{kg}^{-1}$. Magnesium, an additive used in some ferrous metals (e.g. ductile iron), was also elevated in the WFSs with a mean concentration of $190 \mathrm{mg} \mathrm{kg}^{-1}$ as compared to $0.10 \mathrm{mg} \mathrm{kg}^{-1}$ in the VSSs. The mean Cu concentration in the WFSs (i.e. $13.9 \mathrm{mg} \mathrm{kg}^{-1}$ ) was about twice that found in the VSSs because a few of the samples were obtained from bronze foundries. Bronze is an alloy consisting mainly of $\mathrm{Cu}$, thus a transfer of $\mathrm{Cu}$ from the casting to the sand can be expected. Kendall (2003) found that sand from a brass (alloy high in Cu and similar to bronze) mold contained elevated $\mathrm{Cu}$ concentrations. While the maximum $\mathrm{Cu}$ concentration in the WFSs was relatively high at $303 \mathrm{mg} \mathrm{kg}^{-1}$, the 50th and 95th percentile concentrations were 5.6 and $38 \mathrm{mg} \mathrm{kg}^{-1}$, respectively, indicating that the majority of WFSs are low in Cu (Table 2). Lastly, the maximum $\mathrm{Co}$ and $\mathrm{Pb}$ concentrations in the WFSs were very high at 77 and $627 \mathrm{mg} \mathrm{kg}^{-1}$, compared to 2.0 and $<4.2$ in the VSSs, respectively. However, the respective 50th percentile concentrations of these metals in the WFSs were only 1.8 and $2.1 \mathrm{mg} \mathrm{kg}^{-1}$. Overall, the total metal concentrations in the WFSs are comparable to those found in other studies of ferrous and non-ferrous waste sands (Dungan, 2006; Dungan and Dees, 2009).

Table 3 presents the metal concentrations in the WFSs by binder type. The green sands contained the greatest mean concentrations of $\mathrm{Al}, \mathrm{Ba}, \mathrm{Fe}, \mathrm{Mg}, \mathrm{Mn}$, and $\mathrm{Zn}$ at 5898, 39, 12,482, 1131, 105, and $37 \mathrm{mg} \mathrm{kg}^{-1}$, respectively. These metals are commonly found within ferrous and non-ferrous metals and become elevated within the green sands as they are reclaimed within foundries. The maximum metal concentrations were associated with green sand from a ductile iron (also called nodular iron) foundry. The maximum $\mathrm{Al}$, $\mathrm{Ba}$, and $\mathrm{Mg}$ concentrations of 15,074, 115 and $4002 \mathrm{mg} \mathrm{kg}$, respectively, is particularly interesting and was likely a result of the ductile iron foundry using these metals to increase graphite nucleation in the iron (Skaland, 2005). Despite the elevated concentrations within the green sands, metal concentrations were similar in most cases to those found in the VSSs, regardless of binder type.

Although most WFS metal concentrations were similar to VSS despite binder type, $\mathrm{Co}$ and $\mathrm{Pb}$ in the WFSs that used the AU binder were elevated. Cobalt and $\mathrm{Pb}$ are present in octanoates, which are used to accelerate the curing velocity of the molds and cores. Depending upon the binder requirements of each foundry, Co and $\mathrm{Pb}$ can range from 0.0007 to $0.004 \%$ and 0.006 to $0.029 \%$ per dry weight of sand, respectively. The mean concentration of $\mathrm{Co}$ and $\mathrm{Pb}$ found in the $\mathrm{AU}$ waste sands was 19 and $163 \mathrm{mg} \mathrm{kg}^{-1}$, with maximum values of 77 and $647 \mathrm{mg} \mathrm{kg}^{-1}$, respectively (Table 3 ). In the VSSs, the respective maximum $\mathrm{Co}$ and $\mathrm{Pb}$ concentrations were relatively low at 2.0 and $<4.2 \mathrm{mg} \mathrm{kg}^{-1}$. The mean $\mathrm{Cu}$ concentration was also slightly elevated in the AU waste sands, with a maximum concentration of $303 \mathrm{mg} \mathrm{kg}^{-1}$. As discussed previously, this is related to the fact that some samples were obtained from a bronze foundry. Other than the AU waste sands, our results suggest that binder type does not generally influence the metal concentrations in the WFSs.

Waste sands from the foundry industry are a valuable byproduct with proven benefits when used as an aggregate replacement in agricultural and geotechnical applications (Jing and Barnes, 1993; Leidel et al., 1994; Partridge et al., 1999). Despite these benefits, the beneficial use WFSs has been constrained by many local and state governments due to uncorroborated concerns over potential contamination with metals. However, recent research has shown that the majority of foundry sands are a low contaminate waste with a low leaching potential when beneficially used in unencapsulated applications (Guney et al., 2006; Deng and Tikalsky, 2008; Stehouwer et al., 2010). Table 4 presents a comparison of mean concentrations of critical trace metals in WFSs and North American surface soils to soil screening levels (SSLs) used in Argentina. These metals, in some cases, can be harmful to human and animal health if found at elevated concentrations in the environment (Adriano, 2001). When compared to native soil concentrations, the mean metal concentrations in the various WFSs were similar in most

Table 4

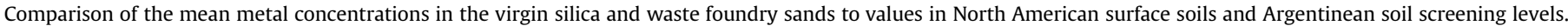

\begin{tabular}{|c|c|c|c|c|c|c|c|c|c|c|c|c|}
\hline \multirow[t]{2}{*}{ Element } & \multicolumn{8}{|c|}{ Mean concentration $\left(\mathrm{mg} \mathrm{kg}^{-1}\right)$} & \multirow{2}{*}{$\begin{array}{l}\text { U.S. and Canadian } \\
\text { soils }\left(\mathrm{mg} \mathrm{kg}^{-1}\right)^{\mathrm{b}}\end{array}$} & \multicolumn{3}{|c|}{ Soil screening levels in Argentina $\left(\mathrm{mg} \mathrm{kg}^{-1}\right)^{\mathrm{c}}$} \\
\hline & VSS & $\mathrm{WFS}^{\mathrm{a}}$ & $\mathrm{AU}$ & PHL & SHL & GS & NAT & UKN & & Agricultural & Residential & Industrial \\
\hline $\mathrm{Ag}$ & 0.35 & 0.35 & 0.35 & 0.35 & 0.35 & 0.35 & 0.35 & 0.35 & $<1.0$ & 20 & 20 & 40 \\
\hline Ва & 14.9 & 17.6 & 13.9 & 13.2 & 13.4 & 39.3 & 13.5 & 18.1 & 530 & 750 & 500 & 2000 \\
\hline $\mathrm{Be}$ & 0.05 & 0.05 & 0.04 & 0.11 & 0.04 & 0.04 & 0.04 & 0.04 & 1.34 & 4 & 4 & 8 \\
\hline $\mathrm{Cd}$ & 0.16 & 0.22 & 0.13 & 0.18 & 0.31 & 0.43 & 0.12 & 0.27 & 0.33 & 3 & 5 & 20 \\
\hline Co & 1.20 & 6.69 & 19.0 & 1.26 & 1.31 & 2.23 & 1.96 & 1.88 & 8.93 & 40 & 50 & 300 \\
\hline $\mathrm{Cr}$ & 666 & 613 & 630 & 638 & 640 & 505 & 648 & 543 & 71.3 & 750 & 250 & 800 \\
\hline $\mathrm{Cu}$ & 6.06 & 13.9 & 21.5 & 5.01 & 8.75 & 18.6 & 11.4 & 21.5 & 14.4 & 150 & 100 & 500 \\
\hline Mo & 9.15 & 8.49 & 8.05 & 8.81 & 10.2 & 6.48 & 8.50 & 9.18 & 1.03 & 5 & 10 & 40 \\
\hline $\mathrm{Ni}$ & 147 & 137 & 137 & 152 & 139 & 105 & 144 & 147 & 34.1 & 150 & 100 & 500 \\
\hline $\mathrm{Pb}$ & 2.10 & 51.4 & 163 & 2.10 & 2.40 & 8.54 & 11.8 & 11.3 & 22.1 & 375 & 500 & 1000 \\
\hline $\mathrm{Tl}$ & 6.00 & 6.00 & 6.00 & 6.00 & 6.00 & 6.00 & 6.00 & 6.00 & 0.47 & 1.0 & - & - \\
\hline V & 5.87 & 7.89 & 6.43 & 5.94 & 8.17 & 14.7 & 6.29 & 7.81 & 59.6 & 200 & 200 & - \\
\hline $\mathrm{Zn}$ & 10.5 & 21.2 & 21.3 & 17.6 & 13.6 & 36.5 & 14.4 & 32.2 & 58.0 & 600 & 500 & 1000 \\
\hline
\end{tabular}

a Mean of all waste foundry sands concentrations, regardless of metal poured and binder type.

b Mean A-horizon concentrations from Smith et al. (2005).

c Soil screening levels from hazardous waste law 24.051 from the Argentinean Ministry of Environment and Sustainable Development (1993). 
cases. While mean $\mathrm{Cr}$, Mo, $\mathrm{Ni}$, and $\mathrm{Tl}$ concentrations in the WFSs were substantially higher than found in the surface soils, this can be attributed to the fact that the VSSs contain naturally elevated concentrations of these metals. The mean $\mathrm{Co}$ and $\mathrm{Pb}$ concentrations in the AU waste sands were also 2.1 and 7.2 times higher than found in the soils, respectively. When mean WFS concentrations were compared to SSLs for agricultural applications in Argentina they were found to be lower, except in the case of Mo and Tl. The agricultural SSLs for Mo and $\mathrm{Tl}$ are 5 and $1 \mathrm{mg} \mathrm{kg}^{-1}$, respectively, and there are no residential and industrial SSLs for Tl. All of the WFS Mo concentrations were at or below the residential SSL of $10 \mathrm{mg} \mathrm{kg}^{-1}$. If metal concentrations in the WFSs are below SSLs, the Argentinean Secretariat of Environment and Sustainable Development should consider them as non-hazardous waste.

\section{Conclusions}

Our results demonstrate that the majority of WFSs analyzed in this study, regardless of metal cast and binder type, contain metal concentrations similar to those found in virgin sands and native soils. In cases where AU binder was used, $\mathrm{Co}$ and $\mathrm{Pb}$ concentrations were elevated in the waste sands. Thus, to avoid contamination of WFSs with these metals, foundries should be encouraged to use alternative binder systems with lower metal concentrations. The elevated $\mathrm{Cr}, \mathrm{Mo}, \mathrm{Ni}$, and $\mathrm{Tl}$ concentrations associated with the virgin sands should not be an issue since these metals are bound within the silica sand matrix. If regulatory agencies do take issue with these metals, however, foundries could purchase source sands with lower concentrations. The fact that $\mathrm{Al}, \mathrm{Ba}, \mathrm{Fe}, \mathrm{Mg}, \mathrm{Mn}$, and $\mathrm{Zn}$ concentrations were elevated in the green sands when compared to the VSSs is of little concern, as these metals are at naturally high concentrations in native soils (Shacklette and Boerngen, 1984) and are not associated with environmental degradation under normal soil conditions (Chaney and Codling, 2005). In fact, $\mathrm{Al}, \mathrm{Fe}$ and $\mathrm{Mn}$ oxides are important sinks for trace metals in soils and byproduct-amended soils (Basta et al., 2005). Because of the naturally low metal concentrations found in most WFSs examined in this study, it is likely they could be beneficially used in both encapsulated and unencapsulated applications without detriment to human and environmental health.

\section{Conflict of interest}

Mention of trade names or commercial products in this publication is solely for the purpose of providing specific information and does not imply recommendation or endorsement by the USDA. The USDA is an equal opportunity provider and employer.

\section{References}

Adriano, D.C., 2001. Trace Elements in the Terrestrial Environments: Biogeochemistry, Bioavailability, and Risks of Heavy Metals, second ed. Springer-Verlag New York.

Argentinean Ministry of Environment and Sustainable Development, 1993 Hazardous Waste Law 24.051. Available at: http://www.ambiente.gov.ar/? aplicacion $=$ normativa $\& I d N o r m a=538 \&$ IdSeccion $=0$ (verified on 14 Jun 2012).

Basta, N.T., Ryan, J.A., Chaney, R.L., 2005. Trace element chemistry in residualtreated soil: key concepts and metal bioavailability. Journal of Environmental Quality 34, 49-63.

Carey, P., January 2002. Sand/Binders/Sand Preparation/\& Coremaking. Foundry Management \& Technology, pp. 39-52.

Chaney, R.L., Codling, E.C., 2005. Bio-based plant nutrient products: heavy metals considerations. Proceedings of bio-based plant nutrient products workshop.
In: Reynelles, R. (Ed.), Bio-based Plant Nutrient Products: Quality Assurance, Marketing and Regulations, pp. 22-36. Seattle, WA.

Deng, A., 2009. Contaminants in waste foundry sands and its leachate. International Journal Environment and Pollution 38, 425-443.

Deng, A., Tikalsky, P.J., 2008. Geotechnical and leaching properties of flowable fill incorporating waste foundry sand. Waste Management 28, 2161-2170.

Dungan, R.S., 2006. Polycyclic aromatic hydrocarbons and phenolics in ferrous and non-ferrous waste foundry sands. Journal of Residual Science and Technology 3, 203-209.

Dungan, R.S., Reeves III, J.B., 2005. Pyrolysis of foundry sand resins: a determination of organic products by mass spectrometry. Journal of Environmental Science and Health 40, 1557-1567.

Dungan, R.S., Reeves III, J.B., 2007a. Pyrolysis of carbonaceous foundry sand additives: seacoal and gilsonite. Thermochimica Acta 460, 60-66.

Dungan, R.S., Reeves III, J.B., 2007b. Near infrared spectroscopic analysis of foundry moulding and core sands. Journal of Near Infrared Spectroscopy 15, 189-194.

Dungan, R.S., Dees, N.H., 2009. The characterization of total and leachable metals in foundry molding sands. Journal of Environmental Management 90, 539-548.

Gardziella, A., Pilato, L.A., Knop, A., 1999. Phenolic Resins: Chemistry, Applications, Standardization, Safety and Ecology, second ed. Springer, New York.

Guney, Y., Aydilek, A.H., Demirkan, M.M., 2006. Geoenvironmental behavior of foundry sand amended mixtures for highway subbases. Waste Management 26, 932-945.

Ham, R.K., Boyle, W.C., Fero, R.L., 1987. Evaluation of organic compounds in groundwater at ferrous foundry waste landfills. American Foundrymen's Society 95, 693-694.

IRAM, 2003. Norma IRAM 29523 determination of the composition of unprocessed urban solid waste. Environmental Quality - Soil Quality 1, 1-22.

Jing, J., Barnes, S., November 1993. Agricultural use of industrial by-products. BioCycle, 63-64.

Kendall, D.S., 2003. Toxicity characteristic leaching procedure and iron treatment of brass foundry waste. Environmental Science \& Technology 37, 367-371.

Leidel, D.S., Novakowski, M., Pohlman, D., MacRunnels, Z.D., MacKay, M.H., 1994. External beneficial reuse of spent foundry sands. AFS Transactions 102, 235-243.

Lindsay, B.J., Logan, T.J., 2005. Agricultural reuse of foundry sand. Journal of Residuals Science \& Technology 2, 3-12.

Miguel, R.E., Ruiz de Galarreta, V.A., Banda Noriega, R.B., 2009. Impacto al recurso hídrico subterráneo por vertedero de residuos de industria de fundición en Tandil, Buenos Aires Argentina: un estudio preliminar. Boletín Geológico y Minero 120, 583-594.

Miguel, R.E., Banda Noriega, R.B., Porta, A.A., 2011. Analysis of Heavy Metals in Leachate from Spent Foundry Sands in Micro, Small and Medium-sized Companies in Argentina. Paper Presented at the 15th Congress of Brazilian Foundry Association, Sao Paulo, Brazil.

Partridge, B.K., Fox, P.J., Alleman, J.E., Mast, D.G., 1999. Field demonstration of highway embankment construction using waste foundry sand. Transportation Research Record 1670, 98-105.

Riediker, S., Ruckstuhl, S., Suter, M.J.F., Cook, A.M., Giger, W., 2000. p-Toluenesulfonate in landfill leachates: leachability from foundry sands and aerobic biodegradation. Environmental Science \& Technology 34, 2156-2161.

Roa, T.V., 2003. Metal Casting: Principles and Practice. New Age International (P) Ltd. Publishers, New Delhi, India.

Shacklette, H.T., Boerngen, J.G., 1984. Element Concentrations in Soils and Other Surficial Materials of the Conterminous United States. U.S. Geological Survey, Professions Paper 1270. U.S. Gov. Printing Office, Washington, DC.

Siddique, R., Schutter, G., Noumowe, A., 2009. Effect of used-foundry sand on the mechanical properties of concrete. Construction and Building Materials 23, 976-980.

Siddique, R., Kaur, G., Rajor, A., 2010. Waste foundry sand and its leachate characteristics. Resources, Conservation, and Recycling 54, 1027-1036.

Skaland, T., 2005. Nucleation Mechanisms in Ductile Iron. Proceedings of the AFS Cast Iron Inoculation Conference, Schaumburg, Illinois.

Smith, D.B., Cannon, W.F., Woodruff, L.G., Garrett, R.B., Klassen, R., Kilburn, J.E., Horton, J.D., King, H.D., Goldhaber, M.B., Morrison, J.M., 2005. Major- and TraceElement Concentrations in Soils from Two Continental-Scale Transects of the United States and Canada. Open-File Report 2005-1253. U.S. Department of the Interior, U.S. Geological Survey, Reston, VA. Available at: http://pubs.usgs.gov/ of/2005/1253/pdf/OFR1253.pdf (verified on 14 Jun 2012).

Stehouwer, R.C., Hindman, J.M., MacDonald, K.E., 2010. Nutrient and trace element dynamics in blended topsoils containing spent foundry sand and compost. Journal of Environmental Quality 39, 587-595.

U.S. EPA, 2007. Microwave Assisted Acid Digestion of Sediments, Sludges, Soils, and Oils (Method 3051A). SW-846 On-line. Available at: http://www.epa.gov/osw/ hazard/testmethods/sw846/pdfs/3051a.pdf (verified on 14 Jun 2012).

Yu, W., He, H., Cheng, N., Gan, B., Li, X., 2009. Preparation and experiments for a novel kind of foundry core binder made from modified potato starch. Materials and Design 30, 210-213. 